\title{
ORGANISASI DAN DESAIN PENGEMBANGAN KURIKULUM
}

\author{
Wahyu Aprilia \\ Universitas Islam Negeri Sunan Kalijaga Yogyakarta \\ 19204010005@student.uin-suka.ac.id
}

\begin{abstract}
The world of education cannot ber separated from the curriculum. The curriculum is one of the most important components of education. The curriculum can cover a broad scope and a narrow scope. A curriculum must have compatibility or relevance with the needs and demands that exist in society. The curriculum must also be able adjust the components in it. In its implementation in a educational institution, the curriculum needs to be developed, in developing a curriculum it certainly cannot be done just like that without reference or guidance. One of the curriculum that is developed must pay attentiom to the organization and design of curriculum development. The organization and design of the curriculum is one aspect that needs to be considered so that in curriculum sevelopment it can meet all the needs and demand of students, educators, and also the community. This study uses the library research method by examining several data sources from books relating to the organization and curriculum development design. The conclusion of this study is that in the process of developing the organizational curriculum it acts as a method for determining the selection and integration of learning experiences held by educational institutions. An organization is very necessary for the management process, namely planning organizations, organizations in the framework or curriculum implementation, and organizations in the framework of curriculum evaluation. In developing curriculum, curriculum design is also needed. Curriculum design is the organization of goals, content, and processes that students will undergo in an educational institution. There are various designs that have been compiled and each design has certain strengths and weaknesses. This study can be a reference for institutions that want to develop a curriculum to understand what organizations and design developments fit their needs. Future research is expected to be able to deal more deeply with the organization and design or curriculum development.
\end{abstract}

Keywords: Organization, Design, Development

\begin{abstract}
Abstrak : Dunia pendidikan tidak dapat terlepas dari kurikulum. Kurikulum adalah salah satu komponen pendidikan yang sangat penting. Kurikulum dapat mencakup lingkup yang luas dan lingkup yang sempit. Kurikulum harus sesuai dengan kebutuhan dan tuntutan yang ada dalam masyarakat. Kurikulum juga harus mampu menyesuaikan komponen-komponen yang ada di dalamnya. Dalam pelaksanaannya di sebuah lembaga pendidikan, kurikulum perlu dikembangkan, dalam mengembangkan kurikulum tentu tidak dapat dilakukan secara begitu saja tanpa acuan atau pedoman. Kurikulum yang dikembangkan salah satunya harus memperhatikan organisasi dan desain pengembangan kurikulum. Pengorganisasian dan desain kurikulum merupakan salah satu aspek yang perlu diperhatikan agar dalam pengembangan kurikulum dapat memenuhi segala kebutuhan dan tuntutan peserta didik, pendidik, dan juga masyarakat. Kajian ini menggunakan metode Library Research dengan mengkaji beberapa sumber data dari buku-buku yang berhubungan dengan organisasi dan desain pengembangan kurikulum. Kesimpulan dari kajian ini adalah organisasi berperan sebagai metode yang digunakan guna menentukan pemilihan dan pengintegrasian berbagai pengalaman belajar yang
\end{abstract}

Islamika : Jurnal Keislaman dan Ilmu Pendidikan

Volume 2, Nomor 2, Juli 2020; 208-226

https://ejournal.stitpn.ac.id/index.php/islamika 
diselenggarakan oleh lembaga pendidikan di dalam proses pengembangan kurikulum. Suatu organisasi sangat diperlkan untuk proses manajemen, yaitu organisasi perencanaan, organisasi dalam rangka pelaksanaan kurikulum, dan organisasi dalam rangka evaluasi kurikulum. Dalam mengembangkan kurikulum juga diperlukan adanya desain kurikulum. Desain kurikulum merupakan pengorganisasian tujuan, isi, serta proses yang akan dijalani peserta didik dalam sebuah lembaga pendidikan. Terdapat berbagai desain yang telah disusun dan masing-masing desain memiliki kelebihan dan kelemahan tertentu. Penelitian ini dapat menjadi referensi bagi lembaga yang ingin mengembangakn kurikulum untuk memhami oragnisasi dan desain pengembangan apa yang sesuai dengan kebutuhannya. Penelitian ke depan diharapkan mampu mnegulas secara lebih mendalam terkai dengan organisasi dan desain pengembangan kurikulum.

Kata Kunci: Organisasi, Desain, Pengembangan

\section{PENDAHULUAN}

Untuk membangun Indonesia yang lebih maju, perlu dipersiapkan generasigenerasi muda yang memiliki kemampuan atau kompetensi yang mumpuni dalam suatu bidang. Pendidikan yang bagus sangat diperlukan untuk membentuk generasi yang melek teknologi dan pengetahuan. Mengingat kondisi dewasa ini, dihadapkan dengan berbagai kemajuan yang pesat dalam segala aspek. Jika tidak sanggup menempuh arus kemajuan yang ada, maka bisa dipastikan bangsa akan mengalami ketertinggalan dan kemunduran. Pendidikan dewasa ini sedang menghadapi rintangan sulit, dari dalam dan luar. Apabila tujuan besar dari pendidikan yang diharap Indonesia dapat tercapai, tentu akan berdampak positif kepada bangsa dan negara.

Agar pelaksanaan pendidikan di suatu lembaga dapat tertata dan memiliki arah yang jelas serta terkoordinasi dengan baik dan sistematis, maka perlu adanya pengelolaan kurikulum agar dapat meraih tujuan pendidikan yang diinginkan. Perlu adanya kajian teoretis dan praktis dalam mengelola kurikulum agar dapat searah dengan perkembangan budaya manusia dan juga kemajuan IPTEK. Dalam menghadapi problem sekolah khususnya dalam proses pembelajaran perlu kebijakan kepala sekolah untuk melibatkan pihak-pihak dalam lembaga seperti pendidik, komite sekolah, dan semua pihak yang terlibat dalam melakukan pengelolaan kurikulum. ${ }^{1}$ Termasuk usaha yang bisa dilakukan adalah melalui pengembangan komponen-

\footnotetext{
${ }^{1}$ Razali M Thaib and Irman Peserta didiknto, "Inovasi Kurikulum Dalam Pengembangan Pendidikan (Studi Analisis Implementatif)," Jurnal Edukasi 1 (2015): 216-228.
} 
komponen pendidikan. Salah satu komponen yang harus dikembangkan adalah kurikulum.

Menurut herlina, melihat esensi dari kurikulum, kurikulum memiliki peranan yang penting dalam memajukan pendidikan bagi negara, Indonesia. Membangun kembali pendidikan dengan mendesain ulang merupakan langkah yang tepat untuk dilakukan. ${ }^{2}$ Peran kurikulum sangat penting dalam pendidikan. Terdapat tiga peranan penting kurikulum yakni konservatif, kritis atau evaluatif, dan kreatif. Ketiga peranan ini perlu diterapkan dengan seimbang. Selain memiliki peranan, kurikulum juga memiliki beberapa fungsi, yaitu penyesuaian, integrasi, diferensiasi, persiapan, pemilihan, dan diagnostik. Beberapa fungsi ini secara penuh diimplementasikan oleh kurikulum. Fungsi tersebut berpengaruh pada tumbuh kembang peserta didik, seiring tujuan pendidikan yang ditetapkan oleh lembaga pendidikan terkait.

Dengan begitu maka kurikulum perlu dikembangkan agar dapat menjalankan perannya. Lembaga-lembaga pendidikan harus mampu mengembangkan kurikulum agar dapat berjalan sempurna dalam proses pembelajaran di lembaga pendidikan tersebut. Pihak-pihak yang terkait dengan kurikulum dalam sebuah lembaga pendidikan harus mengerti serta memahami tentang kurikulum dan komponenkomponennya. Karena setelah kurikulum diputuskan, maka lembaga pendidikan harus bisa mengimplementasikan dengan baik kurikulum tersebut di lembaganya. Perlu adanya pengembangan komponen-komponen dalam kurikulum yang harus dilakukan. Dengan adanya pengembangan kurikulum ini, diharapkan tujuan pendidikan yang ditetapkan oleh masing-masing lembaga dapat tercapai maksimal. Salah satu upaya dalam pengembangan kurikulum perlu dilakukan pengorganisasian dan desain kurikulum.

Menurut Aset Sugiana, dalam mengorganisasi kurikulum harus disusun dengan semaksimal mungkin untuk mencapai tujuan pendidikan yang diharapkan. Beberapa hal yang harus diperhatikan dalam mengorganisasi kurikulum yakni, melihat kebutuhan, minat, dan bakat peserta didik yang berbeda-beda. ${ }^{3}$ Pengorganisasian

\footnotetext{
${ }^{2}$ Herlina, "Urgensi Desain Kurikulum Dalam Upaya Memajukan Pendidikan Di Indonesia," Ngabari: Jurnal Studi Islam Dan Sosial 11 (2018): 15.

3 Aset Sugiana, "Proses Pengembangan Organisasi Kurikulum Di Indonesia," El-HiKMAH Jurnal Kajian Dan Penelitian Pendidikan Islam 12 (2018): 91-103.
} 
kurikulum adalah bentuk penyusunan bahan ajar atau materi yang akan diajarkan kepada peserta didik. Dengan adanya pengorganisasian kurikulum, diharapkan kurikulum akan memenuhi berbagai kebutuhan, tuntutan, harapan, permasalahan yang dialami peserta didik, pendidik, maupun masyarakat. Selain pengorganisasian kurikulum perlu dilakukan perencanaan, validasi, implementasi dan evaluasi yang merupakan bagian dari desain kurikulum. Dalam mendesain kurikulum harus memerhatikan berbagai prinsip yang dijadikan acuan. Dengan memahami organisasi dan desain pengembangan kurikulum, sebuah lembaga akan mampu mengorganisasi dan mendesain kurikulum yang digunakannya dengan sedemikian baik agar dapat membawa lembaga atau sekolahnya kepada pencapaian tujuan pendidikan yang ditentukan. Untuk mengetahui lebih lanjut tentang apa organisasi kurikulum dan desain pengembangan kurikulum, dalam kajian ini akan dipaparkan sedikit mengenai organisasi dan desain pengembangan kurikulum.

\section{METODE PENELITIAN}

Metode yang dipakai dalam penelitian ini adalah Library Research yaitu kajian pustaka atau kajian literatur. Kajian pustaka adalah proses penelitian yang metode pengumpulan datanya berupa data pustaka, yang diperoleh dari kegiatan membaca literatur dab mencatat serta mengolah data yang menjadi bahan penelitian. ${ }^{4}$ Pada kajian pustaka sumber data berupa buku, jurnal, artikel, berita, koran, majalah, atau sumber lain yang berkaitan dan sesuai dengan masalah yang sedang diangkat.

\section{ORGANISASI KURIKULUM}

Organisasi kurikulum adalah bahan pelajaran yang akan diajarkan pada peserta didik. Organisasi kurikulum termasuk dasar yang penting dalam pembinaan kurikulum. Organisasi kurikulum memiliki ikatan kuat dengan tujuan pendidikan yang ingin diraih. Hal ini dikarenakan organisasi kurikulum ikut menentukan aspek-aspek yang diperlukan dalam proses pembelajaran. ${ }^{5}$ Kerangka-kerangka umum program pembelajaran yang hendak disampaikan pada peserta didik merupakan organisasi

${ }^{4}$ Mustika Zed, Metode Penelitian Kepustakaan (Jakarta: Yayasan Obor Indonesia, 2014), 3.

${ }^{5}$ Nasution, Asas-Asas Kurikulum (Jakarta: Bumi Aksara, 1995), 176. 
kurikulum. Dalam kegiatan pengembangan kurikulum, organisasi memiliki peran sebagai cara atau langkah untuk menentukan pemilahan dan pengorganisasian berbagai pengalaman belajar yang diadakan oleh lembaga pendidikan. ${ }^{6}$

Organisasi merupakan suatu kelompok sosial yang sifatnya tertutup atau terbuka dari/terhadap pihak luar, yang berada di bawah aturan tertentu, dipimpin oleh seorang pimpinan/staf administratif, yang dapat melaksanakan bimbingan secara teratur dan bertujuan. Suatu organisasi sangat diperlukan untuk memulai proses manajemen, yaitu: ${ }^{7}$

1. Organisasi perencanaan dilaksanakan oleh lembaga pengembang kurikulum atau suatu tim pengembang kurikulum.

2. Organisasi dalam rangka pelaksanaan.

3. Organisasi dalam evaluasi kurikulum.

Setiap organisasi kurikulum memiliki ciri khusus sendiri, memiliki tuntutan sendiri seperti tuntutan terhadap pendidik, media, administrasi sekolah, dan tuntutan lain untuk melaksanakan kurikulum itu. ${ }^{8}$ Organisasi kurikulum begitu berhubungan dengan pengelolaan bahan pelajaran dalam kurikulum, sedangkan sumber bahan pelajaran dalam kurikulum adalah nilai budaya, nilai sosial, aspek peserta didik dan masyarakat, serta ilmu pengetahuan dan teknologi. Sejumlah faktor yang musti dipertimbangkan dalam organisasi kurikulum, yang pertama, ruang lingkup dan urutan bahan pelajaran. Ruang lingkup dan sistematika bahan pelajaran merupakan salah satu faktor yang perlu diperhatiakan dalam suatu kurikulum. Setiap pola kurikulum memiliki ruang lingkup materi pelajaran yang tidak sama. Selain lingkup materi pelajaran, bagaimana urutan bahan tersebut harus disajikan dalam kurikulum juga perlu diperhatikan dalam organisasi kurikulum. Kedua, organisasi kurikulum, kontinuitas kurikulum terutama yang berkaitan dengan substansi bahan yang dipelajari peserta didik perlu untu diperhatikan. Pendekatan spiral termasuk salah satu upaya penerapan dari faktor ini. Artinya, materi yang diterima peserta didik semakin lama semakin

\footnotetext{
${ }^{6}$ Sukiman, Pengembangan Kurikulum: Teori Dan Praktik Pada Perpendidikan Tinggi (Yogyakarta: Fakultas Ilmu Tarbiyah dan Kependidikan UIN Sunan Kalijaga, 2013), 75-76.

${ }^{7}$ Oemar Hamalik, Manajemen Pengembangan Kurikulum (Bandung: Remaja Rosdakarya, 2012), 136137.

${ }^{8}$ Muhammad Zaini, Pengembangan Kurikulum Konsep, Implementasi, Evaluasi, Dan Inovasi. (Yogyakarta: Teras, 2009), 63.
} 
mendalam yang dikembangkan berdasarkan keluasan kajian. Ketiga, dalam organisasi kurikulum, keseimbangan bahan pelajaran perlu dipertimbangkan juga. Semakin dinamis perubahan dan perkembangan dalam ilmu pengetahuan, sosial budaya, maupun ekonomi mempengaruhi dimensi kurikulum. Keempat. alokasi waktu yang dibutuhkan dalam kurikulum harus menjadi bahan pertimbangan dalam proses pengorganisasian kurikulum. ${ }^{9}$

Dalam pemilihan dan pengorganisasian kurikulum diperlukan suatu prosedur seperti (1) Employee. Peran pendidik sangat penting, hal ini disebabkan pemilihan dan pengorganisasian kurikulum ditentukan berdasarkan penguasaan isi kurikulum tersebut di kalangan pendidik, baik secara individu maupun kelompok. (2) Buku mata pelajaran. Dalam prosedur ini untuk menentukan isi dari kurikulum didasarkan pada materi yang terdapat di buku pelaajran yang dipilih oleh panitia tertentu. (3) Survei pendapat. Dalam prosedur ini pemilihan, pengorganisasian, atau pengorganisasisan kembali isi kurikulum dimulai dengan mengidentifikasi pendapat beberapa pihak dengan survei. (4) Studi kesalahan. Prosedur ini adalah menganalisis kesalahan dan lelemahan dari pengalaman belajar, misalnya dengan memerhatikan tingkah laku yang didibentuk melalui kurikulum tersebut. (5) Mempelajari kurikulum lainnya. Bisa dikatakan sebagai metode "tambal sulam". Yaitu mempelajari bagaimana kurikulum di sekolah lain, pendidik atau sekolah dapat melaksanakan dan menentukan isi kurikulum bagi lembaganya, yang sejalan dengan tujuan yang diharapkan. (6) Analisis kegiatan orang dewasa. Langkah pertama adalah mempelajari berbagai kegiatan atau aktivitas yang ada dalam kehidupan. Hal tersebut memiliki tujuan untuk menemukan kegiatan apa yang nantinya dapat berguna bagi peserta didik di lingkungan sekolahnya. (7) Fungsi-fungsi sosial. Prosedur ini berhubungan dengan analisis kegiatan, tetapi memiliki pandangan yang sedikit lebih luas. Masyarakat dewasa melakukan banyak fungsi sosial dalam kehidupan sehari-hari. Ada berbagai macam fungsi, dan pada dasarnya berada dalam daerah kehidupan tertentu yang tidak terlepas dari situasi kehidupan secara total. Oleh karena itu, fungsi yang telah ditemukan kemudian diklasifikasikan menjadi "areas of living". (8) Minat dan kebutuhan remaja. Scope prosedur ini ditentukan berdasarkan berbagai fungsi kehidupan orang dewasa yang diklasifikasikan menjadi "areas of

\footnotetext{
${ }_{9}^{9}$ Rusman, Manajemen Kurikulum (Jakarta: Rajawali Pers, 2009), 60-61.
} 
persistent life problems". Adapun sequence dari prosedur ini didasarkan pada latar belakang, kematangan, minat dan kebutuhan para peserta didik secara kronologis dan logis. Dalam menjalankan prosedur atau langkah ini, perlu melibatkan persistent problems, dengan scope dan urutannya didasarkan pada para peserta didik itu sendiri dan berkaitan juga dengan kegunaan secara personal dan sosial, selain untuk menyusun kesiapan menjalani kehidupan berikutnya. ${ }^{10}$

Bentuk-bentuk organisasi kurikulum di antaranya sebagai berikut:

1. Kurikulum Mata Pelajaran (Isolated Subject atau Subjectmatter Curriculum)

Organisasi kurikulum ini digolongkan sebagai bentuk kurikulum yang masih tradisonal. Kurikulum ini telah lama digunakan pada sekolah-sekolah dulu, hingga muncul kurikulum baru pada tahun 1968 dan kurikulum tahun 1975. Beberapa ciri dari bentuk kurikulum ini adalah terdiri dari (1) sejumlah mata pelajaran yang tidak tergabung antara satu pelajaran dengan pelajaran yang lainnya (masingmasing pelajaran berdiri sendiri), (2) setiap pelajaran seakan memiliki ruang dan waktu tertentu, (3) hanya bertujuan pada penguasaan ilmu pengetahuan tanpa memperhatikan aspek tingkah laku lainnya, (4) tidak berdasar dari kebutuhan, minat, dan masalah yang dihadapi peserta didik, (5) tidak mempertimbangkan kebutuhan, masalah, dan tuntutan masyarakat yang selalu berkembang, (6) metodologi atau pendekatan yang digunakan adalah imposisi dan menciptakan perbedaan di antara kalangan peserta didik, (7) peran pendidik sangat aktif dalam proses pembelajaran, dan (8) peserta tidak dilibatkan dalam perencanaan kurikulum secara kooperatif. ${ }^{11}$

2. Kurikulum dengan Mata Pelajaran Berkorelasi

Melihat adanya keterpisahan antara mata pelajaran, maka ada upaya baru untuk menghubungkan berbagai mata pelajaran untuk membuat para peserta didik mudah dalam memperoleh pemahaman. Ini bisa disebut kurikulum dengan pelajaran yang berkorelasi. Pola korelasi ini terdiri dari 2 macam, korelasi informal

\footnotetext{
${ }^{10}$ Rusman.

11 Oemar Hamalik, Dasar-Dasar Pengembagan Kurikulum (Bandung: Remaja Rosdakarya, 2017), 155156.
} 
dan korelasi formal. ${ }^{12}$ Korelasi informal, seorang pendidik mata pelajaran meminta agar pendidik mata pelajaran lain menghubungkan pelajaran yang akan diajarkan di kelas dengan bahan yang telah dipersiapkan oleh pendidik pertama. Sebagai contoh, pendidik Sejarah akan mengajarkan sejarah Perang Diponegoro. Kemudian, pendidik ini meminta pendidik Ilmu Bumi untuk membahas tentang daerah geografis terjadinya Perang Diponegoro tersebut. Selanjutnya pendidik Bahasa diminta supaya memberikan pelajaran bercerita tentang suasana masyarakat sewaktu terjadinya perang. ${ }^{13}$

Sedang korelasi formal, beberapa pendidik secara kolektif merencanakan untuk mengorelasikan mata pelajaran yang menjadi tanggung jawabnya sendiri. Dengan cara, para pendidik bersangkutan lebih dulu menentukan fokus permasalahan. Misal, para pendidik menentukan topik tentang "keluarga". Pendidik yang mengampu pelajaran Bahasa memberikan cerita yang berhubungan dengan kehidupan keluarga, pendidik yang mengampu pelajaran Menyanyi mengajarkan nyanyian pengantar tidur, pendidik yang mengajar Ilmu Berhitung memberikan catatan anggaran belanja dalam keluarga. Selanjutnya terus begitu, sehingga para pendidik mata pelajaran lainnya dapat memberikan sumbangan terhadap pembahasan topik tersebut. ${ }^{14}$ Ciri kurikulum ini adalah mengorelasikan berbagai mata pelajaran, ada usaha untuk menghubungkan pelajaran dengan permasalahan kehidupan meskipun tujuannya masih dalam lingkup penguasaan ilmu pengetahuan, mulai mengupayakan penyesuaian pelajaran dengan minat dan kemampuan peserta didik meski pelayanan terhadap perbedaan individual masih sangat terbatas, menggunakan metode korelasi, meskipun terdapat banyak kesulitan, dan meski pendidik masih berperan aktif, namun aktivitas peserta didik sudah mulai dikembangkan.

3. Kurikulum Bidang Studi

Menurut pandangan sejumlah ahli, kurikulum bidang studi ini termasuk dalam jenis kurikulum berkorelasi. Pandangan para ahli ini ada benarnya dikarenakan bidang studi sudah merupakan perpaduan atau fusi sejumlah mata

12 Hamalik, 156.

${ }^{13}$ Hamalik, 156-157.

${ }^{14}$ Hamalik, 157. 
pelajaran sejenis, yang memiliki ciri-ciri yang mirip. Ciri-ciri kurikulum ini (1) terdiri dari pengajaran yang di dalamnya terdapat perpaduan antara sejumlah mata pelajaran, sejenis dan memiliki ciri-ciri yang sama, (2) pelajaran bertitik tolak dari core subject, yang kemudian diuraikan menjadi sejumlah pokok bahasan, (3) berdasar pada tujuan kurikuler dan tujuan instruksional yang telah digariskan, (4) sistem penyampaian bersifat terpadu, (5) peran pendidik selaku pendidik bidang studi, (6) penyusunan kurikulum mempertimbangkan minat, masalah, serta kebutuhan peserta didik dan masyarakat meskipun masih dalam batas tertentu, (7) terdapat berbagai jenis bidang studi. ${ }^{15}$

4. Kurikulum Terintegrasi

Dalam kurikulum terintegrasi adanya batas-batas antara semua mata pelajaran sudah tidak terlihat dikarenakan semua mata pelajaran sudah dirumuskan dalam bentuk unit. Semuanya sudah terintegrasi atau terpadu sebagai satu kesatuan yang utuh. Ciri dari kurikulum ini antara lain, (1) berdasarkan filsafat pendidikan demokrasi, (2) berdasarkan psikologi belajar Gestalt atau organismik. (3) berlandaskan sosiologis dan sosial budaya. (4) berdasarkan kebutuhan, minat, dan tingkat perkembangan atau pertumbuhan peserta didik. (5) lebih luas, tidak hanya ditunjang oleh mapel yang ada. Bahkan bisa saja mata pelajaran baru muncul dan digunakan sebagai pemecah masalah. (6) sistem penyampaian yang digunakan adalah sistem pengajaran unit, baik experience unit atau subject matter unit. (7) peran pendidik dan peserta didik sama-sama aktif. Bahkan peran peserta didik bisa lebih dominan dalam kegiatan belajar-mengajar dan pendidik hanya berperan sebagai pembimbing. ${ }^{16}$

5. Kurikulum Inti

Ciri-ciri kurikulum ini :

\section{a. Essential characteristics}

1) Core pelajaran meliputi pengalaman yang penting untuk pertumbuhan dan perkembangan semua peserta didik.

${ }^{15}$ Hamalik, 157-158.

${ }^{16}$ Hamalik, 158. 
2) Core program berkenaan dengan pendidikan umum untuk memperoleh berbagai hasil.

3) Kesatuan dari kegiatan dan pengalaman inti.

4) Waktu pelaksanaan yang lama..

b. Ciri-ciri

1) Direncanakan dengan kooperatif dari pendidik.

2) Unit-unit pengalaman belajar yang luas dan kompreehensif.

3) Prosesnya yang demokratis..

4) Pendidik bertanggung jawab sebagai pembimbing.

5) Pembelajaran yang fleksibel dan bervarian serta sumber belajar yang luas..

6) Menggunakan metode problem solving. .

7) Pendidik dan peserta didik memiliki hubungan yang baik.

8) Memiliki bermacam bentuk penilaian dan dilakukan secara berkelanjutan dan utuh.

9) Pengalaman belajar yang fungsional serta bertanggung jawab terhadap peserta didik.

10) Berupaya memperbaiki proses pembelajaran.

\section{DESAIN PENGEMBANGAN KURIKULUM}

Desain kurikulum merupakan pengorganisasian tujuan, isi serta kegiatan belajar yang akan dijalani oleh peserta didik pada berbagai tahap perkembangan pendidikan. Dalam desain kurikulum akan tergambar berbagai unsur kurikulum, hubungan antara satu unsur dengan unsur lainnya. ${ }^{17}$ Desain kurikulum menurut Fred Percival dan Henry Ellington adalah pengembangan proses perencanaan, validasi, implementasi, dan evaluasi kurikulum. Selanjutnya, Saylor mengajukan 8 prinsip sebagai acuan dalam mendesain kurikulum, sebagai berikut: ${ }^{18}$

1. Memudahkan dan mendorong pemilihan serta pengembangan semua jenis pengalaman belajar yang mendasar bagi pencapaian prestasi belajar.

${ }^{17}$ Hamdani Hamid, Pengembangan Kurikulum Pendidikan (Bandung: Pustaka Setia, 2012), 32.

${ }^{18}$ Hamalik, Dasar-Dasar Pengembagan Kurikulum, 193-194. 
2. Berisi semua pengalaman belajar yang bermakna dalam upaya mencapai tujuantujuan pendidikan, khususnya bagi peserta didik yang belajar dengan bimbingan pendidik.

3. Menyediakan kesempatah bagi pendidik untuk menggunakan prinsip-prinsip belajar dalam memilih, membimbing, dan mengembangkan berbagai kegiatan belajar di sekolah.

4. Memungkinkan pendidik untuk menyesuaikan pengalaman dengan kebutuhan, kapasitas, dan kematangan peserta didik.

5. Mendorong pendidik mempertimbangkan berbagai pengalaman belajar anak yang diperoleh dari luar sekolah dan mengaitkannya dengan kegiatan belajar di sekolah.

6. Menyediakan pengalaman belajar yang berkesinambungan, agar kegiatan belajar peserta didik berkembang sejalan dengan pengalaman terdahulu dan terus berlanjut pada pengalaman berikutnya.

7. Kurikulum harus didesain supaya bisa memberikan bantuan kepada peserta didik dalam upaya mengembangkan watak, kepribadian, pengalaman, dan nilai-nilai demokrasi yang menjiwai kultur.

8. Realistis, layak, dan dapat diterima.

Desain kurikulum diartikan sebagai susunan dari berbagai unsur kurikulum yang terdiri dari tujuan, isi, pengalaman belajar, dan evaluasi. Karakteristik penting dalam sebuah kurikulum salah satunya adalah konseptualisasi dan organisasi berbagai bagian dari kurikulum tersebut. Dalam organisasi kurikulum, desain kurikulum berhubungan dengan organisasi horizontal dan organisasi vertikal. Organisasi horizonal sering disebut sebagai cakupan atau integrasi horizontal yang berhubungan dengan susunan komponen-komponen kurikulum, sedangkan organisasi vertikal sebagai sekuens, yang perhatiannya terletak pada hubungan antara komponenkomponen kurikulum. ${ }^{19}$

Desain kurikulum merupakan aspek yang amat penting dari curriculum planning karena menunjukkan elemen-elemen yang harus diperhatikan dalam perencanaan kurikulum dan hubungan elemen-elemen ini dalam proses pengembangan kurikulum, merupakan cara untuk menentukan pemilahan organisasi berbagai pengalaman belajar

${ }^{19}$ Hamalik. 
yang diselenggarakan di sekolah, dan menentukan peranan pendidik, peserta didik, dan orang lain yang terlibat dalam perencanaan kurikulum. ${ }^{20}$ Menurut Musyarapah, mendesain kurikulum adalah menyusun rancangan atau menyusun model sesuai dengan visi dan misi lembaga pendidikan. Konteks dari pengembangan kurikulum secara spesifik adalah untuk dapat memenuhi kebutuhan individual dan kebutuhan dari lembaga itu sendiri. Dalam menganalisis kebutuhan, ada beberapa tahap yang harus dilakukan, di antaranya: membuat keputusan mengenai need assessment, memperoleh informasi, dan menggunakan informasi. ${ }^{21}$ Beberapa langkah dalam mendesain kurikulum adalah, 1) mengidentifikasi misi yang ingin dicapai oleh institusi atau lembaga, menentukan kebutuhan peserta didik, menetapkan tujuan dari kurikulum, memilih strategi pendidikan yang tepat, mengimplemetasikan kurikulum terbaru, evaluasi dan umpan balik untuk memperbaiki kekurangan yang ada dalam sebuah kurikulum. ${ }^{22}$

Para pengembang kurikulum telah mengonstruksi kurikulum menurut dasar-dasar pengategorian berikut:

\section{Subject-centered design.}

Desain yang berpusat pada mata pelajaran. Suatu desain kurikulum yang berpusat pada bahan ajar, yang teridri dari 3 desain, yaitu subject design, disciplines design, dan broad fields design. Bentuk desain ini termasuk dalam kategori desain yang paling tua, dan terpopuler serta paling banyak digunakan. Subject centered design berkembang dari konsep pendidikan klasik yang menekankan pengetahuan, nilai-nilai dan warisan kultur masa silam, dan berusaha untuk mewariskannya kepada generasi berikutnya. Kurikulum ini disebut juga subject academic curriculum karena dalam kurikulum ini menomorsatukan isi atau bahan ajar. ${ }^{23}$

Model desain ini mempunyai kelebihan dan kekurangan, kelebihan dari desain ini antara lain mudah a) disusun, dilaksanakan, dievaluasi dan disempurnakan, b)

\footnotetext{
${ }^{20}$ Hendyat Soetopo and Wasty Soemanto, Pembinaan Dan Pengembangan Kurikulum Sebagai Substansi Problem Administrasi Pendidikan (Jakarta: Bina Aksara, 1986), 75.

${ }^{21}$ Musyarapah, "Manajemen Proses Pengembangan Kurikulum (Need Assesment Dan Pengembangan

Desain Kurikulum)," Jurnal Al-Risalah 10 (2014): 227-40.

22 Ahmad Mukhlasin and Rakhmat Wibowo, "Desain Pengembangan Kurikulum Integratif Dan Implementasinya Dalam Pembelajaran,” Jurnal Tawadhu 2 (2018): 364-80.

${ }^{23}$ Nana Syaodih Sukmadinata, Pengembangan Kurikulum Teori Dan Praktik (Bandung: Remaja Rosdakarya, 2013), 113-114.
} 
pendidik cukup menguasai ilmu atau bahan ajar sering dipandang mampu menyampaikannya. Sedang kekurangan dalam desain kurikulum ini adalah a) tidak sesuai dengan kenyataan, sebab dalam kenyataan pengetahuan itu merupakan satu kesatuan yang tidak terpisah, b) peserta didik berperan sangat pasif, c) pembelajaran lebih ditekankan pada pengetahuan dan kehidupan masa lalu, sehingga pembelajaran lebih bersifat verbalistis dan kurang praktis. ${ }^{24}$

a. Subject Design

Subject design adalah bentuk design yang paling murni dari subject centered design. Materi ajar disampaikan dengan terpisah dalam bentuk mata pelajaran. Ketika abad 19 pendidikan lebih cenderung ke arah yang bersifat praktis, terkait dengan pencaharian. Pada saat ini mulai berkembang mata pelajaran IPA, bahasa yang masih bersifat teoretis, juga mata pelajaran praktis seperti pertanian, ekonomi, dan lain-lain. Bahan ajar diambil dari pengetahuan, dan nilai yang sebelumnya telah ditemukan oleh peneliti terdahulu. Peserta didik diharuskan menguasai semua pengetahuan yang telah disampaikan oleh pendidik, baik suka taupun tidak. Pelajaran yang diberikan secara-terpisah, mmenjadikan penguasaan materi oleh peserta didik harus terpisah juga. Sehingga tidak jarang peserta didik hanya menghafal karena menguasai pengetahuan secara verbalitas. ${ }^{25}$

Kelemahan dari desain ini adalah (1) memberikan pengetahuan yang terpisah-pisah, (2) diambil dari masa lalu, (3) kurang memperhatikan minat, kebutuhan, dan pengalaman peserta didik, (4) sering menimbulkan kesukaran dalam mempelajari dan menerapkannya, dan (5) kurang memberi perhatian pada cara penyampaian. Sedangkan kelebihan dari desain ini adalah sebagai berikut: (1) penyusunan materinya cukup mudah, (2) penerapannya mudah, (3) memudahkan peserta didik untuk mengikuti pendidikan di Perpendidikan Tinggi, sebab di Perpendidikan Tinggi umumnya menggunakan desain ini, (4) dapat dilaksanakan secara efisien, karena metode utamanya adalah metode ekspositori yang dikenal tingkat efisiennya cukup tinggi, dan (5) sangat tepat digunakan sebagai alat untuk melestarikan dan mewariskan budaya. Dari kelemahan itu, pihak yang sedang

24 Sukmadinata, 114.

25 Sukmadinata, 114-115. 
mengembangkan kurikulum subject design berusaha untuk membenahinya. Broad fields design merupakan pengembangan dari desain ini, termasuk juga pengembangan di luar subject centered, seperti activity atau experience design, dan lainnya.

b. Disciplines Design

Desain ini termasuk pengembangan dari subject design, keduanya sama-sama berfokus pada isi atau materi kurikulum. Keduanya memiliki perbedaan, pada subject design belum ada kriteria yang tegas tentang apa yang disebut subject. Belum ada perbedaan antara matematika, psikologi dengan teknik atau cara mengemudi, semuanya disebut subject. Sedang pada disciplines design kriteria tersebut telah tegas, yang membedakan apakah suatu pengetahuan itu ilmu atau subject dan bukan batang tubuh keilmuannya. Batang tubuh keilmuan menentukan apakah suatu bahan ajar itu disiplin ilmu atau bukan.

Dalam disciplines design, isi kurikulum yang diberikan di sekolah berupa berbagai disiplin ilmu. Disciplines design tidak seperti subject design yang menekankan penguasaan fakta-fakta dan informasi tetapi pada pemahaman. Peserta didik didorong untuk memahami struktur dasar disiplin, konsep-konsep, ide-ide, dan beberapa prinsip penting, juga didorong untuk memahami cara mencari dan menemukannya. Pembelajaran sudah menggunakan pendekatan inkuiri dan discovery. ${ }^{26}$

Kelebihan dari desain ini adalah (1) selain memiliki organisasi yang terstruktur dan tepat guna, desain ini juga mampu menjaga integritas intelektua pengetahuan, dan (2) peserta didik mampu menguasai konsep, relevansi dan proses intelektual yang berkembang pada peserta didik. Sedangkan kekurangan desain ini, (1) pengetahuan yang terintegrasi belum sanggup diberikan, (2) belum mampu menggabungkan antara sekolah dengan masyarakat atau kehidupan, (3) belum bertolak dari minat dan kebutuhan atau pengalaman peserta didik, (4) susunan kurikulum belum efisien baik untuk kegiatan belajar maupun untuk

${ }^{26}$ Sukmadinata, 115-116. 
penggunaannya, serta (5) meski sudah lebih luas dari subject design tapi secara akademis dan intelektual masih sempit.

\section{c. Broad Fields Design}

Salah satu usaha untuk menghilangkan pemisah dalam subject design dan disciplines design adalah dengan broad fields design. Dalam model ini terjadi penyatuan mata pelajaran yang masih memiliki korelasi menjadi satu fokus mata pelajaran. Yang ingin dicapai dari pengembangan broad fields design ini adalah membentuk peserta didik yang saat ini sedang hidup dalam dunia informasi yang sifatnya khusus, dengan pemahaman yang menyeluruh. Desain ini lebih banyak digunakan di SD dan SMP. ${ }^{27}$

Nilai tambah dari desain ini adalah (1) Memungkinkan penyusunan warisan-warisan budaya secara terstruktur. (2) Memungkinkan peserta didik menemukan hubungan antara bermacam hal. Sedangkan kelemahan dari desain ini adalah (1) kemampuan pendidik, pada sekolah dasar pendidik mampu menguasai bidang yang luas, tetapi di jenjang yang lebih tinggi apalagi di perpendidikan tinggi sangat sulit, (2) karena bidang yang dipelajari luas, maka tidak dapat diberikan secara mendetail, yang diajarkan hanya permukaannya saja, (3) mengintegrasikan bahan ajar yang terbatas sekali, tidak menggambarkan kenyataan, tidak memberikan pengalaman yang sesungguhnya bagi peserta didik, sehingga belum maksimal dalam membangkitkan minat belajar, dan model ini menekankan tujuan penguasaan bahan dan informasi, kurang menekankan proses pencapaian tujuan yang sifatnya sikap dan pengetahuan tingkat tinggi.

\section{Learner-centered design.}

Desain yang berpusat pada pembelajar. Suatu desain kurikulum yang mengutamakan peran peserta didik. ${ }^{28}$ Ciri utama yang menjadi pembeda desain model learner centered design dengan subject centered. Pertama, learned centered design mengembangkan kurikulum dengan bertolak dari peserta didik, bukan dari isi. Kedua, learned centered design bersifat not-preplanned (kurikulum yang tidak diorganisasikan sebelumnya) tetapi dikembangkan bersama antara pendidik dan

27 Sukmadinata, 116-117.

${ }^{28}$ Hamalik, Dasar-Dasar Pengembagan Kurikulum, 195. 
peserta didik. Organisasi kurikulum didasarkan pada masalah atau tema yang menarik fokus pendidik dan dibutuhkan peserta didik serta sekuennya disesuaikan dengan tingkat perkembangan mereka. ${ }^{29}$

Salah satu bentuk dari desain ini adalah model desain Activity atau Ekperience Design. Beberapa ciri utama dari model design ini adalah yang pertama, struktur kurikulum dipilih berdasarkan kebutuhan dan minat peserta didik. Kedua, kurikulum disusun oleh para pendidik dan peserta didik. Ketiga, menekankan prosedur pemecahan masalah. Berbeda dengan subject design yang lebih menekankan isi, activity design lebih memperhatikan proses. ${ }^{30}$

Kelebihan dari desain ini adalah (1) motivasi belajar bersifat intrinsik, (2) pembelajaran memperhatikan perbedaan individual, (3) kegiatan-kegiatan pemecahan masalah memberikan bekal kecakapan dan pengetahuan untuk menghadapi kehidupan di luar sekolah. Sedangkan kritik tentang kelemahan dari desain ini adalah (1) penekanan pada minat dan kebutuhan peserta didik belum tentu cocok dan memadai untuk menghadapi kenyataan dalam kehidupan, (2) tidak memiliki pola dan struktur, (3) activity design sangat lemah dalam kontinuitas dan sekuens bahan, dan (4) sulit menemukan referensi yang dapat dipakai sebagai sumber belajar karena buku yang ada disusun berdasarkan subject atau discipline design.

3. Problem-centered design.

Desain yang pusatnya adalah problem. Desain kurikulum yang berpusat pada masalah yang dihadapi dalam kehidupan masyarakat. ${ }^{31}$ Berbeda dengan learned centered design, kurikulum model desain ini telah disusun sebelumnya. Isi kurikulum berupa berbagai masalah sosial yang dihadapi peserta didik masa kini dan masa yang akan datang. Penyusunan sekuens didasarkan pada kebutuhan, kepentingan, dan kemampuan peserta didik. Problem centered design ini menekankan pada isi maupun perkembangan peserta didik. ${ }^{32}$

\footnotetext{
${ }^{29}$ Sukmadinata, Pengembangan Kurikulum Teori Dan Praktik, 118.

${ }^{30}$ Sukmadinata.

${ }^{31}$ Hamalik, Dasar-Dasar Pengembagan Kurikulum, 195.

32 Sukmadinata, Pengembangan Kurikulum Teori Dan Praktik, 120.
} 
Salah satu model dari problem centered design adalah Areas of living design. Dalam model ada penggabungan antara tujuan yang sifatnya proses dengan tujuan yang sifatnya isi. Pemberian rangsangan pada penguasaan materi yang sifatnya pasif. Menggunakan pengalaman dan situasi nyata peserta didik sebagai pembuka jalan dalam mempelajari kehidupan merupakan ciri lain dari desain ini. Pengalaman masing-masing peserta didik sangat erat kaitannya dengan berbagai bidang kehidupan, jadi dapat dikatakan suatu desain kurikulum apabila bidangbidang kehidupan yang dirumuskan dengan baik akan merangkum bermacam pengalaman sosial peserta didik. Selain manarik minat, design ini mendekatkan peserta pada pemenuhan kebutuhan hidupdalam masyarakat.

Kelebihan dari design ini antara lain: (1) masalah kehidupan sosial menjadi penghapus pemisah antar subject, (2) mengarahkan pada penggunaan metode belajar pemecahan masalah. (3) menyiapkan materi dalam bentuk yang sesuai, yakni untuk memecahkan masalah-masalah dalam kehidupan. (4) menyiapkan materi dalam bentuk yang fungsional, dan (5) motivasi belajar datang dari faktor internal peserta didik. Beberapa kelemahan dari desain ini adalah (1) sangat sukar menentukan ruang lingkup dan sekuens dari sisi kehidupan yang sangat esensial, (2) kurangnya integritas dan kontinuitas organisasi isi kurikulum, (3) mengabaikan warisan budaya, (4) ada kecenderungan untuk mengindoktrinasi peserta didik dengan kondisi yang ada, peserta didik tidak melihat alternatif lain, baik mengenai masa lalu atau masa yang akan datang, dan (5) pendidik, mengalami hambatan dikarenakan belum adanya buku atau media lain untuk membantu pelaksanaannya. ${ }^{33}$ Masing-masing design tersebut dikembangkan menjadi rancangan kurikulum yang di dalamnya terdapat unsur-unsur pokok kurikulum, yaitu tujuan, isi, pengalaman belajar, dan evaluasi, yang sesuai dengan inti setiap model design. ${ }^{34}$

33 Sukmadinata.

${ }^{34}$ Hamalik, Dasar-Dasar Pengembagan Kurikulum, 194-195. 


\section{KESIMPULAN}

Organisasi kurikulum adalah bentuk bahan pelajaran yang akan disampaikan kepada peserta didik. Organisasi kurikulum merupakan dasar yang penting dalam pembinaan kurikulum. Organisasi kurikulum sangat erat hubungannya dengan tujuan pendidikan yang hendak dicapai. Hal ini dikarenakan organisasi kurikulum ikut menentukan aspek-aspek yang diperlukan dalam proses pembelajaran. Organisasi kurikulum merupakan kerangka umum pembelajaran yang akan diberikan bagi peserta didik. Dalam proses pengembangan kurikulum, organisasi berperan sebagai metode untuk menentukan seleksi dan pengorganisasian pengalaman-pengalaman belajar yang diselenggarakan oleh lembaga pendidikan.

Desain kurikulum merupakan pengorganisasian tujuan, isi serta proses belajar yang akan diikuti peserta didik pada berbagai tahap perkembangan pendidikan. Dalam desain kurikulum, terlihat gambaran unsur-unsur kurikulum dan hubungan antar unsur. Desain kurikulum menurut Fred Percival dan Henry Ellington adalah pengembangan proses perencanaan, validasi, penerapan, dan evaluasi kurikulum. Setiap design dikembangkan menjadi suatu rancangan kurikulum yang memuat berbagai unsur pokok kurikulum, yaitu tujuan, isi, pengalaman belajar, dan evaluasi, yang sesuai dengan inti setiap model design.

\section{DAFTAR PUSTAKA}

Aset Sugiana. "Proses Pengembangan Organisasi Kurikulum Di Indonesia." ElHiKMAH Jurnal Kajian Dan Penelitian Pendidikan Islam 12 (2018): 91-103.

Hamalik, Oemar. Dasar-Dasar Pengembagan Kurikulum. Bandung: Remaja Rosdakarya, 2017.

. Manajemen Pengembangan Kurikulum. Bandung: Remaja Rosdakarya, 2012.

Hamid, Hamdani. Pengembangan Kurikulum Pendidikan. Bandung: Pustaka Setia, 2012.

Herlina. "Urgensi Desain Kurikulum Dalam Upaya Memajukan Pendidikan Di Indonesia." Ngabari: Jurnal Studi Islam Dan Sosial 11 (2018): 15.

Mukhlasin, Ahmad, and Rakhmat Wibowo. "Desain Pengembangan Kurikulum Integratif Dan Implementasinya Dalam Pembelajaran.” Jurnal Tawadhu 2 (2018): 364-80.

Musyarapah. "Manajemen Proses Pengembangan Kurikulum (Need Assesment Dan Pengembangan Desain Kurikulum).” Jurnal Al-Risalab 10 (2014): 227-40. 
Nasution. Asas-Asas Kurikulum. Jakarta: Bumi Aksara, 1995.

Rusman. Manajemen Kurikulum. Jakarta: Rajawali Pers, 2009.

Soetopo, Hendyat, and Wasty Soemanto. Pembinaan Dan Pengembangan Kurikulum Sebagai Substansi Problem Administrasi Pendidikan. Jakarta: Bina Aksara, 1986.

Sukiman. Pengembangan Kurikulum: Teori Dan Praktik Pada Perpendidikan Tinggi. Yogyakarta: Fakultas Ilmu Tarbiyah dan Kependidikan UIN Sunan Kalijaga, 2013.

Sukmadinata, Nana Syaodih. Pengembangan Kurikulum Teori Dan Praktik. Bandung: Remaja Rosdakarya, 2013.

Thaib, Razali M, and Irman Peserta didiknto. "Inovasi Kurikulum Dalam Pengembangan Pendidikan (Studi Analisis Implementatif).” Jurnal Edukasi 1 (2015): 216-28.

Zaini, Muhammad. Pengembangan Kurikulum Konsep, Implementasi, Evaluasi, Dan Inovasi. Yogyakarta: Teras, 2009.

Zed, Mustika. Metode Penelitian Kepustakaan. Jakarta: Yayasan Obor Indonesia, 2014. 